\title{
Coconut mite, Acathrix trymatus (Keifer) ${ }^{1}$
}

W. C. Welbourn ${ }^{2}$

\section{Introduction}

Coconuts, Cocos nucifera (Arecaceae), are an important world crop. In Florida, coconut palms are used as an important part of tropical landscapes. Coconut palms are hosts to at least 12 species of Eriophyidae in nine genera worldwide. Three species of eriophyid mites have been found on Florida coconut palms (Keifer 1962a, c; 1965). Keifer (1962a, c) described two species in 1962: Acritonotus denmarki Keifer and Amrinus coconuciferae (Keifer). Amrinus coconuciferae was originally placed in the genus Acamina by Keifer (1962a), but was transferred to Amrinus by Flechtmann (1994). This mite is a leaf vagrant and is not known to damage coconut palms or their fruit. Acritonotus denmarki Keifer, was described from a Florida royal palm (Roystonis elata), and can damage fronds (Keifer 1962c) of the royal and coconut palms. A third species, Aceria guerreronis Keifer was described in 1965 from coconuts in Mexico (Keifer 1965) and confirmed in Florida in 1984 (Howard et al. 1990). The coconut mite, A. guerreronis, damages floral bracts and scars developing coconuts in West Africa, Brazil, and throughout the Carribean region, including Mexico, Colombia, and Venezuela (Howard et al. 1990).
In 1996, a fourth eriophyid mite, Acathrix trymatus, was discovered on the newly emerging coconut fronds on Grassy Key (Monroe County) by Mr. Jon G. Rackley. Acathrix trymatus was originally described by Keifer (1962b) from specimens collected in the folds of newly emerging coconut fronds in the Philippines. Keifer's generic name, Acathrix, means "short seta" for the minute scapular setae on the prodorsal sclerite of this species (Keifer 1962b). Briones (1963) investigated A. trymatus and three other eriophyid species on Philippine coconut palms and found their feeding did little damage and did not transmit cadang-cadang disease.

\section{Distribution}

Acathrix trymatus is only known from coconut palms in the Philippines and Florida. In Florida, it has been found on coconut palms from the Keys (Monroe County) northward along the east coast to Jupiter (Palm Beach County). It is not known how or when this mite arrived in Florida or its distribution outside Florida and the Philippines.

1. This document is EENY-194 (originally published as DPI Entomology Circular 383), one of a series of Featured Creatures from the Entomology and Nematology Department, Florida Cooperative Extension Service, Institute of Food and Agricultural Sciences, University of Florida. Published: January 2001. This document is also available on Featured Creatures Website at http://creatures.ifas.ufl.edu. Please visit the EDIS Website at http://edis.ifas.ufl.edu.

2. W. C. Welbourn, Florida Department of Agriculture and Consumer Services, Division of Plant Industry.

The Institute of Food and Agricultural Sciences (IFAS) is an Equal Employment Opportunity - Affirmative Action Employer authorized to provide research, educational information and other services only to individuals and institutions that function without regard to race, creed, color, religion, age, disability, sex, sexual orientation, marital status, national origin, political opinions or affiliations. For information on obtaining other extension publications, contact your county Cooperative Extension Service office. Florida Cooperative Extension Service / Institute of Food and Agricultural Sciences / University of Florida / Larry R. Arrington, Interim Dean 


\section{Description}

This tiny ( 0.1 to $0.2 \mathrm{~mm}$ ) wormlike mite is whitish in color. The species and genus is distinguished by the presence of a median pit just posterior to the prodorsal shield. Other distinguishing characters include prodorsal sclerite with longitudinal striations; scapular setae (sc) minute and set on prominent tubercles; $\mathrm{c} 1$ setae present; external vertical (ve) setae present; opisthosomal annuli narrow and subequal dorsoventrally; and the pretarsal empodium elongate with 11 to 12 rays.

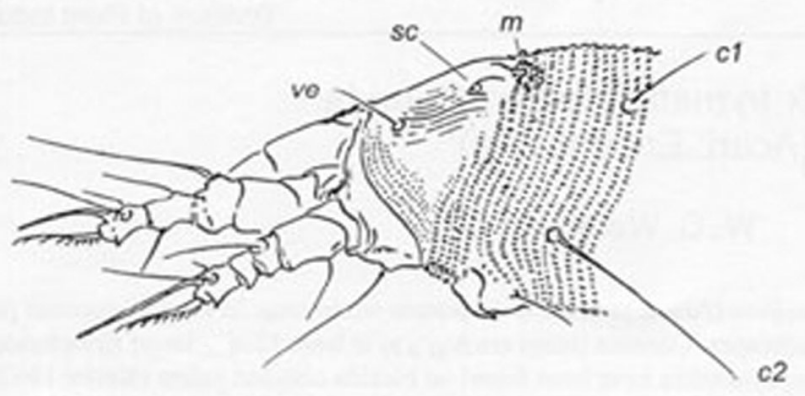

Figure 1. Antero-lateral view (ve - external vertical seta; $m$ - median pit; sc - scapular seta). Credits: Division of Plant Industry, modified from Keifer (1962b)

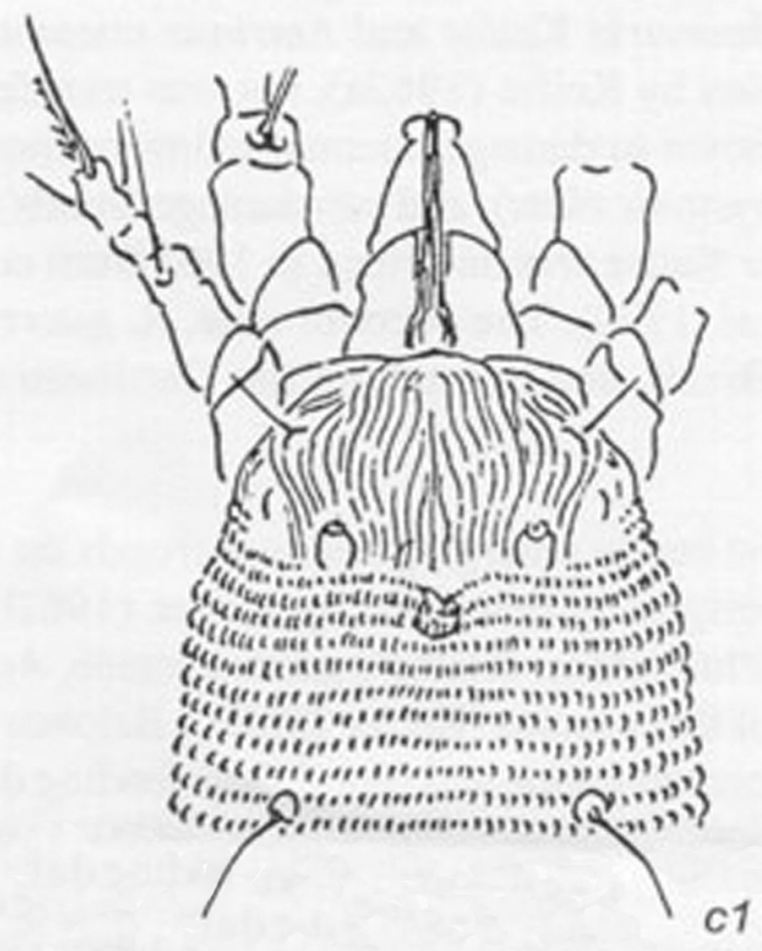

Figure 2. Antero-dorsal view. Credits: Division of Plant Industry, modified from Keifer (1962b)

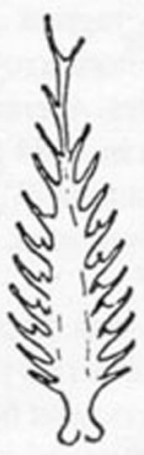

Figure 3. Empodium (featherclaw). Credits: Division of Plant Industry, modified from Keifer (1962b)

\section{Survey and Detection}

This mite can be found only in folds of newly emerging coconut fronds. Sampling for this mite requires removal of a portion of the newly emerging frond and examining the folded pinnae (leaflets) with a good hand lens or a dissecting microscope. Briones (1963) reported finding A. trymatus on old as well as young foliage, but in Florida the mites have only been found on the newly emerging fronds. The best time to survey for these mites is late fall though spring because the mite is difficult to detect in the summer.

\section{Damage}

Although A. trymatus can have large populations on some coconut palms, it does not appear to damage the developing coconut leaves. There is no evidence that this mite transmits any diseases to the coconut palm. However, the mites seemed to be more common on palms showing the symptoms of lethal yellowing disease. Two species of predatory mites were found with A. trymatus in Monroe County: one was a cheyletid, Cheletominus duosetosus Muma (Cheyletidae) and the other was a phytoseid, Neoseiulus sp. (Phytoseiidae).

\section{Selected References}

Briones, M.L. 1963. Habitat, gross morphology and geographical distribution of four new species of eriophyid mites from coconut in the Philippines. FAO Plant Protection Bulletin 11: 25-30. 
Flechtmann, C.H.W. 1994. Amrineus cocofolius

N.G., N.SP. (Acari: Eriophyidae) from Brazil.

International Journal of Acarology 20: 57-59.

Howard, F.W., E. Abreu-Rodriguez, and H.A.

Denmark. 1990. Geographical and seasonal

distribution of the coconut mite, Aceria guerreronis

(Acari: Eriophyidae), in Puerto Rico and Florida,

USA. Journal of the Agricultural University of Puerto

Rico 74: 237-251.

Keifer, H.H. 1962a. Eriophyid studies B-6.

Bureau of Entomology, California Department of

Agriculture, Sacramento. 20 p.

Keifer, H.H. 1962b. Eriophyid studies B-7. Bureau of Entomology, California Department of Agriculture, Sacramento. 20 p.

Keifer, H.H. 1962c. Eriophyid studies B-8. Bureau of Entomology, California Department of Agriculture, Sacramento. 20 p.

Keifer, H.H. 1965. Eriophyid studies B-14. Bureau of Entomology, California Department of Agriculture, Sacramento. 20 p. 